\title{
PENINGKATAN HASIL BELAJAR SISWA KELAS X MIA SMA NEGERI 27 MALUKU TENGAH DENGAN MENGGUNAKAN PENDEKATAN CONTEXTUAL TEACHING AND LEARNING (CTL) PADA MATERI SISTEM PERSAMAAN LINIER TIGA VARIABEL
}

\author{
Samsudin Mahu1, Tanwey Gerson Ratumanan ${ }^{2 *}$, Hanisa Tamalene ${ }^{3}$ \\ 1, 2,3Prodi Pendidikan Matematika Fakultas Keguruan dan Ilmu Pendidikan, Universitas Pattimura \\ Jalan Ir. M. Putuhena, Kampus Unpatti, Poka, Ambon, Indonesia \\ e-mail: ${ }^{1}$ samsudinmahu49@gmail.com; ${ }^{2}$ tanweyratumanan@gmail.com; ${ }^{3}$ tamalene80nissa@gmail.com; \\ Submitted: February 8, $2021 \quad$ Revised: February 15, 2021 \\ Accepted: February 17, 2021 \\ corresponding author*
}

\begin{abstract}
Abstrak
Penelitian ini bertujuan untuk meningkatkan hasil belajar siswa dengan menggunakan pendekatan Contextual Teaching and Learning (CTL) pada materi sistem persamaan linier tiga variabel di kelas X MIA SMA Negeri 27 Maluku Tengah. Pendekatan Contextual Teaching and Learning dengan tujuh komponen utama (contructivisme, inquiry, questioning, learing community, modeling, dan authentic assesment) merupakan pembelajaran yang mengaitkan materi pelajaran dengan kehidupan nyata. Penelitian ini merupakan Penelitian Tindakan Kelas (PTK) yang berlangsung selama 2 siklus. Subjek dalam penelitian ini adalah siswa kelas X MIA1 SMA Negeri 27 Maluku Tengah yang berjumlah 27 orang. Pengumpulan data dilakukan menggunakan observasi dan tes akhir pada setiap siklus. Teknik analisis data yang digunakan adalah teknik analisis data kualitatitif dan kuantitatif. Pada siklus I terdapat 13 orang yang mencapai nilai kriteria Ketuntasan Minimal (KKM) yaitu $\geq 70$ atau dengan persentase ketuntasan 48, 14\%, Sedangkan pada siklus II, terdapat 23 orang $(85,18 \%)$ yang mencapai KKM. Dengan demikian, dapat disimpulkan bahwa pembelajaran dengan menggunakan pendekatan Contextual Teaching and Learning (CTL) dapat meningkatkan hasil belajar siswa kelas X MIA SMA 27 Maluku pada materi sistem persamaan linier tiga variabel.
\end{abstract}

Kata Kunci: pendekatan contextual teaching and learning (ctl), hasil belajar

\section{IMPROVING STUDENT LEARNING OUTCOMES CLASS X MIA SMA NEGERI 27 MALUKU TENGAH BY USING AN APPROACH CONTEXTUAL TEACHING AND LEARNING (CTL) ON THREE VARIABLE LINEAR EQUATION SYSTEM MATERIALS}

\begin{abstract}
The purpose of this research to improve student learning outcomes by using the approach Contextual Teaching and Learning (CTL) on three variable linear equation system materials in the class X MIA SMA Negeri 27 Maluku Tengah. Approach contextual teaching and learning with seven main components (contructivisme, inquiry, questioning, learing community, modeling, dan authentic assesment) is a learning that associates the subject matter with real life. This research is a Class Action Research lasts for 2 cycles. The subject in this study were 27 students of class X MIA1 SMA Negeri 27 Maluku Tengah. Data collection is carried out using observations and final tests on each cycle. Techniques data analysis used are quality and quantitative. In cycle I there are 13 student that achieved the criteria value Criteria Minimal Completion is $\geq 70$ or by completion percentage $48,14 \%$. While in cycle II, there are 23 student that reach the Minimum Completion Criteria with a percentage of $85,18 \%$. Thus, it can be concluded that learning using a Contextual Teaching and Learning (CTL) can improve student learning outcomes class X MIA SMA Negeri 27 Maluku Tengah on the three-variable linear equation system material.
\end{abstract}

Keywords: approach contextual teaching and learning (ctl), three variable linear equation system

Copyright $(\odot)$ Authors. This is an open access article distributed under the Attribution-NonCommercialShareAlike 4.0 International (CC BY-NC-SA 4.0), which permits unrestricted use, distribution, and reproduction in any medium, provided the original work is properly cited. 


\section{Pendahuluan}

Matematika merupakan ilmu universal yang mendasari perkembangan teknologi modern. Matematika memiliki peran penting dalam berbagai disiplin dan memajukan daya pikir manusia. Perkembangan pesat di bidang teknologi informasi dan komunikasi dewasa ini dilandasi oleh perkembangan matematika di bidang teori bilangan, aljabar, analisis, teori peluang dan matematika diskrit. Untuk menguasai dan menciptakan teknologi di masa depan diperlukan penguasaan matematika yang kuat sejak dini (Ratumanan dan Mattitaputty, 2017).

Matematika dipandang sebagai mata pelajaran yang sulit, kurang menarik, dan menakutkan. Menurut Ratumanan dan Laurens (2016) menjelaskan bahwa matematika dianggap sebagai mata pelajaran yang sulit, membosankan, tidak menarik, dan bahkan cenderung dianggap momok bagi sebagian besar siswa. Hal ini disebabkan karena pembelajaran matematika yang cenderung monoton, strukturalis, kurang menarik, dan kurang kontekstual.

Cara pandang dan pembelajaran yang kurang tepat akan berdampak pada hasil belajar matematika siswa. Menurut Ratumanan dan Laurens (2016) rata-rata penguasaan objek langsung matematika lulusan SMA di Provinsi Maluku sebesar 26,96, terdiri atas penguasaan konsep matematika sebesar 31,61, penguasaan operasi matematika sebesar 27,02 , dan penguasaan prinsip matematika sebesar 22,26. Tingkat penguasaan objek langsung matematika tersebut berada dalam kategori "sangat rendah". Selanjutnya, rata-rata penguasaan objek tak langsung matematika lulusan SMA di Provinsi Maluku sebesar 31,33, terdiri atas kemampuan pemecahaan masalah sebesar 22,26 dan kemampuan penalaran sebesar 40,39. Tingkat penguasaan objek tak langsung matematika tersebut berada dalam kategori "sangat rendah".

Pada tingkat SMP, Ratumanan dan Ayal (2018) menemukan bahwa hanya 3,125\% siswa yang memiliki penguasaan matemari sangat baik, 9,373\% siswa memiliki penguasaan baik, $18,75 \%$ siswa memiliki penguasaan cukup, 39,375\% memiliki penguasaan kurang, dan 29,375\% siswa memiliki penguasaan materi sangat kurang. Juga ditemukan bahwa hanya $1,25 \%$ siswa yang memiliki kemampuan berpikir tingkat tinggi dalam kategori baik, sebagian besar siswa memiliki kemampuan berpikir tingkat tinggi dalam kategori sangat rendah $(70,625 \%)$ dan rendah $(20 \%)$.

Rendahnya tingkat penguasaan siswa terhadap materi matematika tersebut disebabkan oleh rendahnya kualitas pembelajaran. Dari hasil pengamatan terhadap kegiatan pembelajaran di kelas X MIA SMA Negeri 27 Maluku Tengah ditemukan bahwa pembelajaran matematika mengabaikan aspek kontekstual. Penyampain materi hanya bersifat pada penekanan rumusrumus dan pemberian soal-soal rutin, kurang menekan pada aspek kehidupan nyata dari materi tersebut. Dari keterangan guru matematika, juga diperoleh informasi bahwa hasil belajar siswa kelas X MIA1 masih sangat rendah. Hal ini dapat dilihat pada hasil ulangan tengah semester ganjil yang menunjukan bahwa terdapat 13 siswa atau 43,33\% dari 30 siswa yang mendapat nilai di bawah KKM, yaitu 70 .

Untuk mengatasi permasalahan di atas, maka dibutuhkan pendekatan yang bermakna untuk meningkatkan hasil belajar para siswa. Salah satu pendekatan pembelajaran yang dapat digunakan untuk meningkatkan hasil belajar siswa dalam pembelajaran matematika adalah pendekatan Contextual Teaching and Learning (CTL). Pemilihan pendekatan Contextual Teaching and Learning (CTL), karena dari berbagai hasil penelitian menunjukkan bahwa pendekatan ini memberikan dampak positif terhadap kompetensi siswa. Penerapan CTL, dapat meningkatkan hasil belajar siswa. Menurut (Sunarti, 2015) pembelajaran dengan Contextual Teaching and Learning (CTL) efektif digunakan untuk meningkatkan kemampuan berpikir kreatif siswa. Lebih lanjut (Hasnawati, 2006) mengemukakan bahwa pendekatan kontekstual merupakan wahana yang sangat tepat bagi guru untuk memberdayakan potensi siswa sesuai dengan kebutuhan serta lingkungan sekolah dan kehidupannya.

Berdasarkan uraian di atas, maka tujuan dalam penelitian ini adalah untuk meningkatkan hasil belajar siswa dengan menggunakan pendekatan Contextual Teaching and Learning (CTL) pada materi sistem persamaan linier tiga variabel di kelas X MIA SMA Negeri 27 Maluku Tengah.

\section{Metode Penelitian}

Tipe penelitian yang digunakan dalam penelitian ini adalah kualitatif dengan tipe Penelitian Tindakan Kelas (PTK). Menurut Kurt Lewin (Tutuhatunewa dan Laurens, 2016:13) model penelitian tindakan kelas memiliki empat tahapan yaitu perencanaan (planning), pelaksanaan (acting), pengamatan (observating), dan refleksi (reflecting). Penelitian ini dilaksanakan di kelas X MIA SMA Negeri 27 Maluku Tengah, Kecematan 
Leihitu Kabupaten Maluku Tengah Jl. Kapitan Ulupaha Seith, pada semester ganjil tahun ajaran 2020/2021. Subjek penelitian adalah siswa kelas X MIA1 SMA Negeri 27 Maluku Tengah tahun ajaran 2020/2021 yang berjumlah 30 siswa, namun sampai akhir penelitian hanya terdapat 27 siswa yang datanya lengkap untuk dianalisis.

Untuk kebutuhan penelitian ini disusun perangkat pembelajaran yang terdiri dari empat Rencana Pelaksanaan Pembelajaran (RPP), empat Lembar Kerja Siswa (LKS), dan empat Bahan Ajar (BA) masing-masing untuk 4 kali pertemuan dalam 2 siklus. Data yang dikumpulkan dalam penelitian ini terdiri atas data kuantitatif berupa hasil tes siswa pada akhir tiap siklus dan data kualitatif berupa hasil observasi guru dan siswa terhadap pelakaksanaan pembelajaran matematika melalui pendekatan Contextual Teaching and Learning (CTL). Hasil tes siswa dianalisis dengan menggunakan statistik deskriptif kemudian dinilai sesuai dengan Kriteria Ketuntasan Minimal (KKM) yang telah ditentukan di SMA Negeri 27 Maluku Tengah, seperti yang terlihat pada tabel berikut:

Tabel 1. Kriteria Ketuntasan Minimal (KKM)

\begin{tabular}{cc}
\hline $\begin{array}{c}\text { Kriteria Ketuntasan } \\
\text { Minimal (KKM) }\end{array}$ & Keterangan \\
\hline$\geq 70$ & Tuntas \\
$<70$ & Belum Tuntas \\
\hline
\end{tabular}

Pembelajaran dikatakan berhasil, jika minimal 65\% siswa mencapai KKM. Jika kriteri ini belum tercapai, maka siklus dalam penelitian tindakan kelas ini akan dilanjutkan kembali setealah dilaksanakan refleksi. Sedangkan untuk data hasil observasi dianalisis menggunakan analisis kualitatif, dengan langkah-langkah analisis (1) reduksi data, (2) penyajian data, dan (3) penarikan simpulan.

\section{Hasil dan Pembahasan}

\subsection{Hasil Penelitian Siklus I \\ 3.1.1. Pertemuan Pertama}

\section{Perencanaan}

Pada tahap perencanaan peneliti mempersiapkan perangkat pembelajaran yaitu (1) Rencana Pelaksanaan Pembelajaran (RPP) pertemuan pertama dan kedua sesuai dengan komponen pendekatan Contextual Teaching and Learning (CTL); (2) Bahan Ajar pertemuan pertama dan kedua; (3) Lembar Kerja Siswa (LKS) pertemuan pertama dan kedua; (4) Soal tes akhir siklus I; (5) Lembar observasi aktivitas guru dan siswa.

\section{Pelaksanaan Tindakan}

Pelaksanaan tindakan melalui pendekatan Contextual Teaching and Learning (CTL) mengacu pada rencana pembelajaran yang telah disiapkan. Meteri yang dipelajari pada siklus I adalah menentukan himpunan penyelesaian sistem persamaan linear tiga variabel pada masalah kontekstual. Kegiatan pembelajaran berlangsung dalam dua kali pertemuan. Pertemuan pertama membahas tentang menentukan himpunan penyelesaian menggunakan metode subtitusi dan metode eliminasi dari Sistem Persamaan Linier Tiga Variabel (SPLTV) pada masalah kontekstual, untuk pertemuan kedua membahas tentang menentukan himpunan penyelesaian sistem persamaan linear tiga variabel pada masalah kontekstual dengan menggunakan metode gabungan (subtitusi dan eliminasi).

\section{Observasi}

\section{a. Hasil Observasi Aktivitas Guru}

Guru membuka pembelajaran dengan mengucapkan salam dan berdoa dan mengecek kehadiran siswa, guru menyampaikan tujuan pembelejaran dan memberikan motivasi terkait materi yang dipelajari. Selanjutnya guru membagi siswa dalam 6 kelompok dengan masing-masing kelompok berjumlah 5 orang. Setelah selesai membagi siswa dalam kelompok, guru kemudian membagi Bahan Ajar dan LKS pertemuan pertama pada setiap kelompok. Kemudian guru mengarahkan siswa untuk memperhatikan ilustrasi pada Bahan Ajar dan memberikan kesempatan untuk siswa bertanya terkait materi yang diberikan jika belum dipahami.

Setelah itu guru memberikan waktu selama 30 menit kepada siswa untuk berdiskusi dalam kelompok menyelesaikan masalah atau soal-soal yang terdapat pada LKS. Ketika siswa berdiskusi, guru mengontrol setiap kelompok dan membimbing siswa jika terdapat masalah yang belum dipahami pada LKS. Setelah waktu diskusi selesai guru meminta masing-masing kelompok untuk mempersentasikan hasil kerja mereka di depan kelas dan memberikan kesempatan kelompok lain untuk menanggapi dan ajukan pertanyaan. Setelah kegiatan diskusi selesai guru mengeecek pemahaman siswa terkait penjelasan dari kelompok yang mempersentasikan kerja kelompok mereka dan kemudian guru bersama siswa membuat kesimpulan terkait materi pembelajaran. Setelah membuat kesimpulan guru memberitahukan siswa tentang materi yang akan dibahas pada pertemuan berikut dan menutup pembelajaran dengan mengucapkan salam. 


\section{b. Hasil Observasi Aktivitas Siswa Dalam Kelompok}

\section{Kelompok 1}

Pada saat diberikan kesempatan berada dalam kelompok. Hanya terlihat siswa MAM, IH, dan NO yang memperhatikan ilustrasi dan fokus pada penjelasan guru sedangkan pesrta didik AT dan SO hanya diam dan tidak memfokuskan perhatian dengan apa yang diperintahkan guru. Kondisi yang sama berlanjut pada saat menyelesaikan masalah yang terdapat pada LKS, siswa AT dan SO tidak bekerja dalam kelompok mereka hanya diam. Siswa MAM dan NO mewakili kelompok I untuk mempersentasikan hasil diskusi mereka. Kemudian bersama-sama dengan guru mereka membuat kesimpulan.

\section{Kelompok 2}

Pada kelompok 2 siswa ketika diberikan waktu untuk berdiskusi, semua siswa pada kelompok dua yang mengikuti arahan guru hanya saja MSK yang tidak memperhatikan bahan ajar dan penjelasan guru. Pada saat guru menyuruh menyelesaikan masalah pada LKS, siswa AAP, $\mathrm{NH}$, dan $\mathrm{SH}$ yang mengamati dan menyelesaikan LKS, sedangkan siswa IM dan MSK hanya diam. Pada saat kelompok II mempersentasikan hasil kerja mereka, siswa SH dan AAP yang mewakili kelompok mereka dan secara aktif menanggapi pertanyaan dari kelompok lain, dan diakhir pembelajaran seluruhnya secara bersama menyimpulkan materi.

\section{Kelompok 3}

Ketika guru meminta kelompok 3 untuk mempelajari bahan ajar, ISK menunjukkan partisipasi yang baik dalam kelompok. Dia aktif mempelajari bahan ajar dan menyelesaikan masalah pada LKS. Sedangkan siswa DS, MAN, RAH, dan SL tidak terlalu aktif dalam dalam kelompok. Siswa MAN dan DS terlibat dalam proses pemecahan masalah. Pada saat mempersentasikan hasil kerja kelompok siswa ISK dan MAN berani menyampaikan hasil diskusi mereka dan hanya siswa ISK yang bisa menjawab pertanyaan dan tanggapan dari kelompok lain. Setelah itu mereka membuat kesimpulan.

\section{Kelompok 4}

Pada kelompok 4 yang terdiri dari siswa DSH, JH, NH, ST, dan SRT terlihat secara keseluruhan kurang aktif dalam kegiatan pembelajaran, maka pada kelompok ini peneliti bersama guru mengarahkan mereka mengikuti pembelajaran dengan baik. Kelompok ini juga didak melakukan presentasi hasil pekerjaan mereka karena belum bisa menjawab pertanyaan yang ada pada LKS.

\section{Kelompok 5}

Semua siswa mengikuti arahan guru kecuali siswa JM yang tidak memperhatikan bahan ajar dan penjelasan guru. Siswa HT, SK, SN, dan IW memperhatikan bahan ajar dan menyelesaikan LKS secara bersama. Ketika guru mengontrol jalannya diskusi siswa SK meminta kepada guru untuk menjelaskan kembali tentang materi yang disampaikan. Saat kelompok lain mempersentasikan hasil kerja kelompok mereka siswa HT, SK, SN, dan IW memperhatikan kelompok yang sedang persentasi. Di akhir pelajaran seluruh menyimpulkan materi.

\section{Kelompok 6}

Seluruh siswa dalam kelompok 6 yang terdiri dari siswa KM, NAA, SFM, WLR, dan RA mengikuti pelajaran dengan baik. Siswa KM tidak terlalu aktif dalam menyelesaikan LKS. Pada saat kelompok lain mempersentasikan hasil kerja kelompok mereka hanya siswa NAA yang berani mengajukan pertanyaan dan memberikan tanggapan. Pada akhir pelajaran seluruh siswa membuat kesimpulan tentang materi yang baru saja dipelajari.

\subsubsection{Pertemuan Kedua}

\section{Observasi}

\section{a. Hasil Observasi Aktivitas Guru}

Guru membuka pembelajaran dengan mengucapkan salam dan berdoa dan mengecek kehadiran siswa, guru menyampaikan tujuan pembelejaran dan memberikan motivasi terkait materi yang dipelajari. Meminta siswa duduk dalam kelompok masing-masing kemudian guru membagi Bahan Ajar dan LKS untuk materi pertemuan kedua. Kemudian guru mengarahkan siswa untuk memperhatikan ilustrasi pada Bahan Ajar dan memberikan kesempatan untuk siswa bertanya terkait materi yang dibahas jika ada yang belum dipahami.

Setelah itu guru memberikan waktu selama 20 menit kepada siswa untuk berdiskusi dalam kelompok menyelesaikan masalah atau soal-soal yang terdapat pada LKS. Ketika siswa berdiskusi, guru mengontrol setiap kelompok dan membimbing siswa jika terdapat masalah yang belum dipahami pada LKS. Setelah waktu diskusi selesai guru meminta masing-masing kelompok untuk mempersentasikan hasil kerja mereka di depan kelas dan memberikan kesempatan kelompok lain untuk menanggapi dan ajukan pertanyaan. Setelah kegiatan diskusi selesai guru 
mengeecek pemahaman siswa terkait penjelasan dari kelompok yang mempersentasikan kerja kelompok mereka dan kemudian guru bersama siswa membuat kesimpulan terkait materi pembelajaran. Kemudian guru memberikan waktu kepada siswa untuk menyelesaikan tes akhir siklus I secara mandiri. Setelah menyelesaiakn tes akhir, guru menutup pembelajaran dengan mengucapkan salam dan meninggalkan kelas.

\section{b. Hasil Observasi Aktivitas Siswa Dalam Kelompok}

\section{Kelompok 1}

Pada saat berdiskusi hanya siswa MAM, IH, $\mathrm{SO}$, dan NO yang memperhatikan ilustrasi pada Bahan Ajar dan fokus sedangkan siswa AT hanya diam. Pada saat mereka diperintahkan untuk menyelesaikan masalah yang pada LKS, siswa AT dan SO tidak terlalu aktif dalam kelompok. Saat kelompok lain mempersentasikan hasil kerja mereka di depan kelas hanya siswa MAM yang mewakili kelompok 1 untuk memberikan tanggapan dan pertanyaan sedangkan yang lainnya hanya diam.

\section{Kelompok 2}

Pada kelompok 2 semua siswa terlihat aktif menyelesaikan masalah pada LKS, siswa AAP dan $\mathrm{NH}$ saling bekerja sama dan saling berbagi pendapat terkait solusi yang ditemukan. Sedangkan siswa SH membantu menjelasakan kembali kepada siswa IM dan MSK terkait apa yang mereak temukan. Pada saat kelompok lain mempersentasikan hasil kerja mereka siswa SH dan AAP yang mewakili kelompok mereka dan secara aktif memberikan pertanyaan, dan diakhir pembelajaran seluruhnya secara bersama menyimpulkan materi yang dipelajari.

\section{Kelompok 3}

Kelompok 3 juga mereka terlihat baik dan fokus dari pertemuan sebelumnya dalam menyelesaikan masalah yang diberikan. Siswa DS, MAN, dan RAH terlihat partisipasi dan memperhatikan siswa ISK dalam menyelesaikan masalah pada LKS. Pada saat kelompok lain mempersentasikan hasil diskusi mereka memberi pertanyaan kepada kelompok lain. Pada akhir pelajaran secara bersama-sama mereka membuat kesimpulan.

\section{Kelompok 4}

Kelompok 4 yang terdiri dari siswa DSH, JH, NH, ST, dan SRT terlihat secara keseluruhan aktif dalam kegiatan pembelajaran, hanya saja $\mathrm{JH}$ secara perlahan dibimbing untuk mengikuti pembelajaran dengan baik. Pada saat persentasi
DSH dan SRT mewakili kelompok untuk mempersentasikan hasil diskusi kelompok mereka, dan siswa DSH yang berani menjawab pertanyaan yang diberikan kelompok lain. Pada akhir pelajaran mereka secara bersama menyimpulkan materi.

\section{Kelompok 5}

Semua siswa pada kelompok ini terlihat aktif dalam menyelesaikan masalah yang ada pada LKS. Saat mempersentasikan hasil kerja kelompok siswa HT dan SK mewakili kelompok $\mathrm{V}$ untuk menjelaskan hasil diskusi kelompok mereka dan aktif dalam menjawab pertanyaan dari kelompok lain. Di akhir pelajaran seluruh siswa menyimpulkan materi.

\section{Kelompok 6}

Seluruh siswa pada kelompok 6 juga terlihat baik dan fokus dalam menyelesaikan masalah yang diberikan dalam LKS. Siswa NAA dan SFM mewakili kelompok untuk mempersentasikan hasil kerja diskusi mereka, dan mereka secara bersamasama memberikan sanggahan dan menjawab pertanyaan yang diberikan dari kelompok lain. Pada akhir pelajaran seluruh siswa membuat kesimpulan apada materi yang baru saja dipelajari.

Pada akhir pertemuan kedua siswa mengikuti tes akhir suklus I dan tes hasil belajar siswa pada siklus I disajikan pada tabel berikut.

Tabel 2. Hasil Tes Akhir Siklus I

\begin{tabular}{|cccc|}
\hline KKM & Frekuensi & $\begin{array}{c}\text { Presentasi } \\
(\mathbf{\%})\end{array}$ & Keterangan \\
\hline$\geq \mathbf{7 0}$ & 13 & 48,14 & Tuntas \\
\hline$<\mathbf{7 0}$ & 14 & 51,86 & Belum Tuntas \\
\hline Jumlah & 27 & 100 & \\
\hline
\end{tabular}

\section{Refleksi}

Refleksi diadakan terhadap hasil tindakan yang dilakukan untuk mengetahui kelebihan dan kekurangan selama proses pelaksanaan pembelajaran pada siklus I. Hasil tes sebagaimana disajikan pada tabel di atas menunjukkan bahwa hanya 13 siswa $(48,14 \%)$ yang mencapai KKM. Ini berarti bahwa Kriteria Ketuntasan Minimal 65\% siswa mencapai KKM belum tercapai. Dengan demikian, penelitian harus dilanjutkan ke siklus kedua. Dari hasil observasi kegiatan pembelajaran pada siklus 1 tersebut dapat diidentifikasi beberapa kelemahan, yakni: (1) Dalam kegiatan pembelajaran guru terlihat belum sempurna dalam menggunakan pendekatan CTL karena terbiasa dengan pendekatan yang sering digunakan guru; (2) Suasan kelas belum efektif sehingga beberapa siswa terlihat sibuk dengan aktiivitasnya sendiri; 
(3) Pada saat guru topik-topik materi terdapat beberapa hal yang terlewatkan. Hal ini mengakibatkan siswa sulit menyelesaikan masalah yang terdapat pada LKS.

\subsection{Hasil Penelitian Siklus II}

\subsubsection{Pertemuan Pertama}

\section{Perencanaan}

Pada tahap ini peneliti mempersiapkan perangkat pembelajaran yang akan digunakan, yaitu (1) Rencana Pelaksanaan Pembelajaran (RPP) pertemuan pertama dan kedua sesuai dengan komponen pendekatan Contextual Teaching and Learning (CTL); (2) Bahan ajar pertemuan pertama dan kedua; (3) Lembar Kerja Siswa (LKS) pertemuan pertama dan kedua; (4) Soal tes akhir; (5) Lembar observasi aktivitas guru dan siswa.

\section{Pelaksanaan Tindakan}

Pelaksanaan tindakan melalui pendekatan Contextual Teaching and Learning (CTL) mengacu pada rencana pembelajaran yang telah disiapkan. Meteri yang dipelajari pada siklus II adalah menentukan himpunan penyelesaian sistem persamaan linear tiga variabel pada masalah kontekstual. Pertemuan pertama membahas tentang membuat model matematika dan menyelesaikan masalah kontekstual yang melibatkan sistem persamaan linear tiga variabel dengan menggunakan metode subtitusi dan metode eliminasi. Sedangkan pertemuan kedua membahas tentang membuat model matematika dan menyelesaikan masalah kontekstual yang melibatkan sistem persamaan linear tiga variabel dengan menggunakan metode gabungan (subtitusi dan eliminasi).

\section{Observasi}

\section{a. Hasil Observasi Aktivitas Guru}

Guru membuka pembelajaran dengan mengucapkan salam dan berdoa dan mengecek kehadiran siswa, guru menyampaikan tujuan pembelejaran dan memberikan motivasi terkait materi yang dipelajari. Selanjutnya guru membagi Bahan Ajar dan LKS pertemuan pertama siklus II pada setiap kelompok. Kemudian guru memberikan kesempatan untuk siswa bertanya terkait materi atau contoh yang ada pada Bahan Ajar dan LKS.

Setelah proses tanya jawab yang selesai, guru memberikan waktu 35 menit kepada siswa untuk berdiskusi dalam kelompok untuk menyelesaikan masalah yang terdapat pada LKS tersebut. Ketika siswa berdiskusi, guru mengontrol setiap kelompok dan membimbing serta menuntun siswa agar lebih aktif. Setelah siswa diminta untuk mempersentasikan hasil kerja mereka di depan kelas dan memberikan kesempatan kelompok lain untuk menanggapi dan ajukan pertanyaan. Kemudian mereka membuat kesimpulan tentang materi yang telah mereka pelajari dan guru memberikan tugas mandiri untuk diselesaikan di rumah sebagai latihan.

\section{b. Hasil Observasi Aktivitas Siswa Dalam Kelompok}

\section{Kelompok 1}

Pada saat diberikan kesempatan bekerja dalam kelompok hanya siswa MAM, IH, dan NO yang memperhatikan dan fokus sedangkan siswa AT dan SO hanya diam dan tidak memfokuskan perhatian pada apa yang diperintahkan guru. Kondisi yang sama berlanjut pada saat menyelesaikan masalah yang terdapat pada LKS, siswa AT dan SO tidak bekerja dalam kelompok mereka terdiam. Siswa MAM dan NO mewakili kelompok I untuk mempersentasikan hasil diskusi mereka. Siswa AT, IH, MAM, NO dan SO bersama dengan guru membuat kesimpulan.

\section{Kelompok 2}

Ketika diberikan waktu untuk berdiskusi, semua siswa pada kelompok dua ini mengikuti arahan guru untuk memperhatikan Bahan Ajar dan LKS. Pada saat guru menyuruh menyelesaikan masalah pada LKS siswa AAP, MSK, NH, dan SH yang mengamati dan menyelesaikan LKS secara kelompok, sedangkan siswa IM hanya diam dan tidak bekerja. Saat mempersentasikan hasil kerja, siswa SH dan AAP yang mewakili kelompok mereka dan secara aktif menanggapi pertanyaan dari kelompok lain. Diakhir pembelajaran seluruhnya secara bersama menyimpulkan materi yang telah dipelajari.

\section{Kelompok 3}

Pada kelompok ini, siswa DS, MAN, RAH, dan SL cukup aktif dalam diskusi kelompok dan menyelesaikan masalah pada LKS. Siswa ISK dan MAN mewakili kelompok mereka untuk mempersentasikan hasil diskusinya dan semua siswa menjawab pertanyaan dan tanggapan dari kelompok lain. Pada akhir pembelajaran semua siswa secara bersama membuat kesimpulan.

\section{Kelompok 4}

Siswa DSH, JH, NH, ST, dan SRT terlihat secara keseluruhan cuckup aktif dalam kegiatan pembelajaran. Mereka terlihat antusias berdiskusi untuk menyelesaikan masalah dalam LKS. Pada saat presentasi siswa DSH dan SRT mewakili kelompok mereka untuk melakukan presentasi dan memberikan pertanyaan kepada kelompok lain. 
Pada akhir pembelajaran mereka secara bersamasama menyimpulkan materi yang dipelajari.

\section{Kelompok 5}

Semua siswa pada kelompok 5 aktif kecuali siswa SN yang tidak memperhatikan bahan ajar dan LKS. Siswa HT, SK, JM, dan IW memperhatikan bahan ajar dan menyelesaikan LKS secara bersama-sama. Saat kelompok lain mempersentasikan hasil kerja kelompok mereka siswa SK memberikan pertanyaan dan tanggapan dan diakhir pembelajaran mereka menyimpulkan materi yang sudah dipelajari.

\section{Kelompok 6}

Siswa dalam kelompok 6 terdiri dari KM, NAA, SFM, WLR, dan RA mengikuti pelajaran dengan baik, dan memperhatikan bahan ajar serta LKS. Siswa RA tidak terlalu aktif dalam menyelesaikan LKS dan pada saat kelompok lain mempersentasikan hasil kerja kelompok mereka hanya siswa NAA dan KM yang mengajukan pertanyaan dan memeberi tanggapan. Pada akhir pembelajaran seluruh siswa membuat kesimpulan atas materi yang telah dipelajari.

\subsubsection{Pertemuan Kedua}

\section{Observasi}

\section{b. Hasil Observasi Aktivitas Guru}

Guru membuka pembelajaran dengan Guru membuka pembelajaran dengan mengucapkan salam dan berdoa dan mengecek kehadiran siswa kemudian membagi bahan ajar dan LKS pertemuan kedua pada setiap kelompok. Setelah guru memberikan kesempatan untuk siswa bertanya terkait materi yang ada pada bahan ajar dan LKS yang belum dipahami.

Setelah proses tanya jawab selesai, guru meminta siswa untuk mengamati bahan ajar dan LKS kemudian mereka diminta untuk berdiskusi dalam kelompok untuk menyelesaikan masalah yang terdapat pada LKS tersebut. Ketika siswa berdiskusi, guru mengontrol setiap kelompok dan membimbing mereka jika terdapat masalah yang belum dipahami pada LKS. Setelah waktu untuk diskusi selesai guru meminta kelompok untuk mempersentasikan hasil kerja mereka di depan kelas. Kemudian memberikan kesempatan kelompok lain untuk menanggapi dan mengaajukan pertanyaan dan membuat kesimpulan tentang materi yang dipelajari. Setelah itu guru memberikan waktu kepada siswa untuk menyelesaikan soal tes akhir siklus II.

\section{c. Hasil Observasi Aktivitas Siswa Dalam Kelompok}

\section{Kelompok 1}

Pada kelompok ini semua siswa MAM, IH, AT, SO, dan NO memperhatikan Bahan Ajar dan LKS yang diberikan oleh guru dan saat mereka diperintahkan untuk menyelesaikan masalah yang pada LKS mereka sangat berpartisipasi dalam diskusi kelompok. Ketika kelompok lain mempersentasikan hasil kerja mereka di depan kelas hanya siswa MAM dan IH yang mewakili kelompok I untuk memberikan tanggapan dan pertanyaan sedangkan yang lainnya hanya diam dan memperhatikan apa yang dijelaskan dari kelompok yang melakukan persentasi. Diakhir pembelajaran mereka bersama-sama dengan guru membuat kesimpulan.

\section{Kelompok 2}

Siswa pada kelompok II juga memperhatikan bahan ajar dan LKS. Pada saat guru menyuruh menyelesaikan masalah pada LKS, siswa AAP, NH, dan SH saling bekerja sama dan saling berbagi pendapat terkait solusi yang ditemukan sedangkan siswa IM dan MSK juga membantu memberikan masukan terkait dengan pemahaman mereka. Pada saat kelompok lain mempersentasikan hasil kerja mereka siswa $\mathrm{SH}$ dan AAP yang mewakili kelompok mereka dan secara aktif memberikan pertanyaan dan diakhir pembelajaran seluruhnya secara bersama menyimpulkan materi yang telah dipelajari.

\section{Kelompok 3}

Secara keseluruhan kelompok ini sudah cukup baik dan aktif dalam pembelajaran, karena semua siswa memperhatikan bahan ajar dan LKS dan mengerjakan LKS sesuai dengan yang diperintahkan. Semua siswa memperhatikan kelompok lain yang sedang mempresentasikan hasil kerja mereka, siswa ISK dan NO mewakili kelompoknya memberikan pertanyaan dan tanggapan kepada kelompok yang persentasi. Diakhir pembelajaran semua siswa bersama dengan guru menyimpulkan materi yang telah dipelajari.

\section{Kelompok 4}

Pada kelompok 4 semua siswa menunjukkan partisipasi dalam memperhatikan Bahan Ajar Dan LKS yang sudah dibagikan oleh guru. Semua siswa aktif dalam kelompok. Pada saat persentasi siswa SRT dan ST mewakili kelompok untuk menjelaskan hasil kerja mereka, dan secara aktif dalam menjawab pertanyaan dari kelompok lain dan diakhir pembelajaran siswa bersama dengan guru membuat kesimpulan tentang apa yang mereka pelajari. 


\section{Kelompok 5}

Semua siswa pada kelompok ini, menunjukkan partisipasi dalam memperhatikan bahan ajar dan mengerjakan LKS. Semua siswa dalam kelompok juga melakukan diskusi dengan baik serta aktif. Pada saat presentasi siswa HT dan JM mewakili kelompok untuk menjelaskan hasil kerja mereka, dan secara aktif dalam menjawab pertanyaan dari kelompok lain. Pada saat akhir pembelajaran siswa semuanya dapat membuat kesimpulan bersama-sama dengan guru.

\section{Kelompok 6}

Seluruh siswa dalam kelompok 6 yang terdiri dari siswa KM, NAA, SFM, dan WLR mengikuti pelajaran dengan baik dan memperhatikan bahan ajar dan LKS. Mereka berdiskusi dengan baik dalam menyelesaikan LKS yang diberikan oleh guru. Siswa NAA dan WLR mewakili kelompok mereka untuk mempersentasikan hasil kerja diskusi, dan mereka secara bersama memberikan sanggahan dan menjawab pertanyaan yang diberikan dari kelompok lain. Pada akhir pembelajaran seluruh siswa membuat kesimpulan tentang materi yang baru saja dipelajari.

Berikut tabel nilai tes akhir siklus II:

Tabel 3. Hasil Tes Akhir Siklus II

\begin{tabular}{cccc}
\hline KKM & Frekuensi & $\begin{array}{c}\text { Presentasi } \\
(\mathbf{\%})\end{array}$ & Keterangan \\
\hline$\geq \mathbf{7 0}$ & 23 & 85,18 & Tuntas \\
\hline$<\mathbf{7 0}$ & 4 & 14,82 & Belum Tuntas \\
\hline Jumlah & 27 & 100 & \\
\hline
\end{tabular}

\section{Refleksi}

Hasil tes pada siklus II menunjukkan bahwa adanya peningkatan dari siklus I yaitu dari 13 siswa yang tuntas dari keseluruhan siswa pada siklus I atau $48,14 \%$ siswa menjadi 23 siswa yang tuntas pada siklus II atau $85,18 \%$ siswa. Ini berarti hasil yang diperoleh telah mencapai ketuntasan secara klasikal yang ditetapkan yaitu $\geq 65 \%$.

\subsection{Pembahasan}

Pelaksanaan pembelajaran yang telah dilakukan pada siklus I dan siklus II yang disesuaikan dengan komponen pendekatan Contextual Teaching and Learning (CTL) yang sesuai dikatakan Nurhadi (2003:31) mempunyai tujuh, komponen yaitu: 1) constuctivisme, 2) inquiry; 3) questioning; 4) learning community; 5) modeling; 6) reflektion; 7) autentic assement.

Hasil penelitian pada siklus I yang dilaksanakan dalam 2 kali pertemuan menunjukkan bahwa pembelajaran pada siklus I belum terlaksana dengan baik. Pada siklus I pelaksanaan pembelajaran belum memenuhi kriteria yang ditetapkan yang disebabkan siswa belum dapat mencapai ketuntasan materi pembelajaran. Siswa belum mampu memecahkan masalah karena rendahnya kemampuan pemahaman mereka terhadap masalah yang diberikan, siswa masih kesulitan dalam menemukan model matematikanya. Selain itu siswa kurang termotivasi dengan apa yang dipelajari.

Pelaksanaan pembelajaran siklus I yang belum optimal berpengaruh terhadap pencapaian hasil belajar siswa, dimana secara klasikal 51,86\% dari total jumlah siswa kelas X MIA1 SMA Negeri 27 Maluku Tengah belum mencapai ketuntasan belajar dan hanya $48,14 \%$ siswa yang mencapai ketuntasan belajar. Selain itu berdasarkan pengamatan aktivitas siswa dalam pembelajaran masih rendah, siswa kesulitan dalam memecahkan masalah terutama membuat model matematikanya. Untuk mempermudah siswa memahami masalah yang diberikan, maka masalah tersebut harus dihubungkan dengan pengalaman siswa atau kehidupan sehari-hari, hal ini membuat siswa tidak merasa asing dengan masalah yang diberikan. Sejalan dengan hal ini tersebut Pearson (Purwanti, 2015: 18) mengemukakan bahwa agar pembelajaran tidak asing bagi siswa, perlu diciptakan lingkungan yang alamiah dan dekat dengan dunia nyata siswa.

Pada siklus II dilakukan perbaikan proses belajar mengajar untuk mengoptimalkan penggunaan pendekatan Contextual Teaching and Learning (CTL). Dalam siklus ini aktifitas siswa sudah mulai meningkat, karena hampir seluruh siswa terlibat secara aktif dalam proses pembelajaran. Pada siklus ini juga penggunaan pendekatan pembelajaran Contextual Teaching and Learning (CTL) sudah berjalan secara optimal dan siswa terlihat aktif yang mengakibatkan hasil belajar mereka juga meningkat. Hal ini dapat dilihat bahwa secara klasikal $85.18 \%$ dari total jumlah siswa kelas X MIA1 SMA Negeri 27 Maluku Tengah dalam pembelajaran matematika sudah mencapai ketuntasan belajar.

Adapun analisis data hasil belajar siswa pada siklus I dan siklus II yang disajikan dalam diagram batang untuk menunjukkan adanya peningkatan hasil belajar siswa setelah pembelajaran dengan pendekatan Contextual Teaching and Learning (CTL) dari siklus I ke siklus II sebagai berikut: 


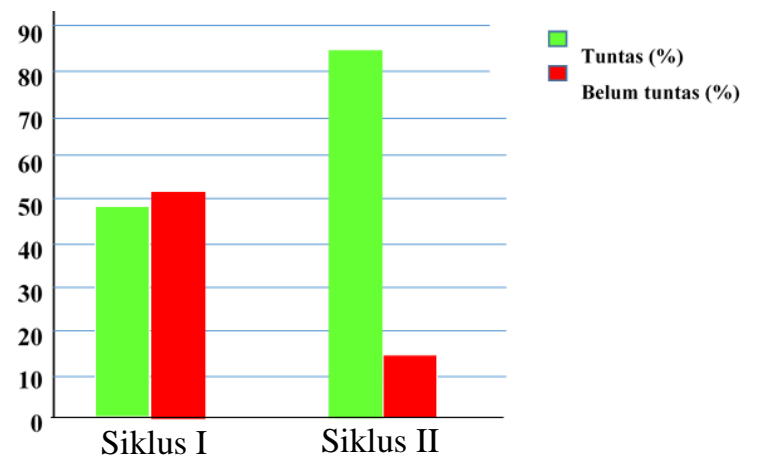

Gambar 1. Diagram Presentase Peningkatan Ketuntasan Belajar

\section{Kesimpulan}

Berdasarkan hasil penelitian yang telah diuraikan, maka dapat disimpulkan bahwa terjadi peningkatan hasil belajar dengan menerapan pendekatan Contextual Teaching and Learning (CTL) yang dilaksanakan pada SMA Negeri 27 Maluku Tengah pada materi sistem persamaan linier tiga variabel dengan peningkatan dari siklus I ke siklus II sebesar 37,04\%. Hal ini dapat dilihat dari hasi tes siklus I yang memperoleh nilai KKM $\geq 70$ sebanyak 13 siswa dengan persentase $48,14 \%$.Selanjutnya pada siklus II terdapat 23 siswa yang memperoleh nilai $\mathrm{KKM} \geq 70$ dengan persentase sebesar $85,18 \%$.

\section{Daftar Pustaka}

Hasibuan, Idrus. (2014). Model Pembelajaran CTL (Contextual Teaching and Learning). Logaritma. Vol. II, No.01 Januari 2014, 1-12.

Hasnawati. (2006). Pendekatan Contextual Teaching Learning Hubungannya Dengan Evaluasi Pembelajaran. Jurnal Ekonomi \& Pendidikan, Volume 3 Nomor 1, April 2006, 53-62.

Hidayat. N. (2014). Penerapan Model Contextual Teaching Learning (CTL) Terhadap Hasil Belajar Siswa Kelas XI SMA Handayani Sungguminahasa Kabupaten Gowa. Makasar. Jurnal Pendidikan Fisika Universitas Muhamaddiyah Makasar. Diunduh pada tanggal 16 Oktober 2020

Johnson, E. B. (2010). Contextual Teaching and Learning: what it is and why it's here to stay (Ibnu Setiawan. Terjemahan). Bandung: MLC. Diunduh pada tanggal 24 Februari 2020

Karim, A. (2017.) Analisis Pendekatan Pembelajaran CTL (Contextual Teaching and Learning) di
SMPN 2 Teluk Jambe Timur Karawang. Jurnal Formatif 7(2), 2017, 144-152.

Lubis, E. A., \& Sembiring, E. L. (2018). Penerapan Model Pembelajaran Contextual Teaching and Learning Dengan Pemberian Handout Untuk Meningkatkan Hasil Belajar Akuntansi Siswa Kelas XII IPS SMA Negeri 1 Bahorok T.P 2017/2018, 9-16.

Nurhadi. (2003). Pembelajaran Kontekstual (Contextual Teaching And Learning/ CTL) dan Penerapannya dalam KBK. Malang: Universitas Negeri Malang.

Purwanti, L. (2015). Upaya Meningkatkan Aktivitas dan Hasil Belajar Matematika Siswa Melalui Pendekatan Pembelajaran Kontekstual Di Kelas VIII SMP Negeri 6 Lubuk Basung. Sumatra Barat. Jurnal STKIP SUMBAR. Media.neliti.com Diunduh pada tanggal 16 Oktober 2020

Ratumanan, T. G., \& C. S. Ayal. (2018). Problem Solving Based Learning Model Alternative Model of Developing High Order Thinking. International Journal of Health Medicine and Current Research (IJHMCR) Vol. 3, Issue 02, June, 2018, pp.857-865.

Ratumanan, T. G., \& Christi Mattitaputty. (2017). Belajar dan Pembelajaran Matematika. Bandung: Alfabeta.

Ratumanan, T. G., \& Theresia Laurens. (2016). Analisis Penguasaan Objek Matematika (Kajian pada Lulusan SMA di Provinsi Maluku). Jurnal Pendidikan Matematika Raflesia, Vol 1, No 2 Desember 2016, hal. 146-154.

Sukinah. (2016). Penerapan Model Pembelajaran Contextual Teaching and Learning Sebagai Upaya Untuk Meningkatkan Prestasi Matematika Materi Peluang. Jurnal Pendidikan Volume 1 Nomor 2 Tahun 2016, 190-204.

Suprianto, S. I. K., \& Herman J. A. (2016). Pengaruh Pendekatan Contextual Teaching and Learning (CTL) Berbantuan Media Powerpoint Terhadap Peningkatan Hasil Belajar Ipa Fisika. JPPI, Vol. 2, No. 2, Desember 2016, Hal. 166-175

Surata, I. K., I Gusti A. A. N. D. M. (2019). Pendekatan Contextual Teaching and Learning (CTL) Berbasis Lembar Kerja Siswa (LKS) Untuk Meningkatkan Aktivitas Belajar Biologi. Bioedusiana 4 (2) (2019), 114-121.

Suryosubroto. (2009). Proses Belajar Mengajaar di Sekolah. Jakarta: PT. Rineka Cipta

Tutuhatunewa, E. \& Laurens, T. 2016. Penelitian Tindakan Kelas. Yogyakarta: Pensil Komunika

Winarti. (2015). Contextual Teaching and Learning (CTL) Untuk Meningkatkan Kemampuan Berpikir Kreatif Siswa. JPFK, Vol. 1 No. 1, Maret 2015: 1-8. 